\title{
Jagdish, Son of Ahmad: Dalit Religion and Nominative Politics in Lucknow
}

Joel Lee

\section{OpenEdition}

\section{Journals}

\section{Electronic version}

URL: http://journals.openedition.org/samaj/3919

DOI: $10.4000 /$ samaj.3919

ISSN: $1960-6060$

\section{Publisher}

Association pour la recherche sur l'Asie du Sud (ARAS)

\section{Electronic reference}

Joel Lee, "Jagdish, Son of Ahmad: Dalit Religion and Nominative Politics in Lucknow », South Asia Multidisciplinary Academic Journal [Online], 11 | 2015, Online since 15 July 2015, connection on 19 April 2019. URL : http://journals.openedition.org/samaj/3919; DOI : 10.4000/samaj.3919

This text was automatically generated on 19 April 2019

\section{(c) () $\ominus$}

This work is licensed under a Creative Commons Attribution-NonCommercial-NoDerivatives 4.0 International License. 


\title{
Jagdish, Son of Ahmad: Dalit Religion and Nominative Politics in Lucknow
}

\author{
Joel Lee
}

'We were Lal Begis. Then when Congress came to power we became Valmiki'-Daulat Ram (son of Anwar). ${ }^{1}$

'The profit that accrued to us upon becoming Hindu [Hindu ban karke], well, it was myriad: many kinds of benefits and schemes, as well as political gains and economic improvement'-Ratan Lal 'Sadhu' (son of Ali).

1 In 1947, members of the caste that supplied most of Lucknow's sanitation labour neither referred to themselves as Valmiki nor were referred to by others as such. As Lalta Prasad, born in 1923, put it to me, 'In my childhood we were all Lal Begis. When I was eight, ten, twelve years old, there was not even mention of the name Valmiki.' The Lal Begis of Lucknow and nearby districts, like their caste fellows across the subcontinent who were variously called Bhangi, Chuhra, Mehtar, and Halalkhor, nurtured a tradition of beliefs and practices centred on a prophet named Lal Beg, from whom they derived their title. The Lucknow Lal Begis had, in 1947, predominantly musalmānā nām, that is, personal names in a Muslim style: female names like Rukhsana, Nazira, and Allah Rakhi; male names like Nabbu, Ramzanu, and Anwar.

2 When I conducted ethnographic and archival research in Lucknow a little over 60 years later, in 2011-12, I met not a single person who referred to himself or herself as Lal Begiat least not initially, and not in mixed company. Most men and many women in the community called themselves Valmiki (or Balmiki, with significance rarely attached to the variation in pronunciation or spelling). Valmiki was also the prevailing term used by others to denote the sanitation labour castes. And in terms of personal names, hinduāna 
nām-names in a Hindu style-predominated: female names like Shanti, Sunita and Asha; male names like Ganesh, Vinod, and Ram Kumar. If one were to assume-as is normatively and consequentially done by everyone from journalists to political scientists to census enumerators-that personal names function as transparent indices of religious identity, then the current generation would appear to be of an entirely different religious community than their grandparents were at the time of Indian independence.

How did this transpire? How did a community come to radically alter its traditional nominative practices, replacing an Islamicate repertoire of names with a brahminical one? What role did the state play in this act of mass resignification, and what does the Lucknow story tell us about related processes that took place elsewhere in north India? Before explaining how this article will address these questions, let me briefly sketch the historical significance of our subject and its scholarly treatment to date.

4 As current controversies over both the 'ghar vāpsì campaigns of the Hindu right and the conversions of Valmikis to Islam in Uttar Pradesh (e.g., The Hindu 2015, Tiwari and Abbas 2015) remind us, the question of the religious affiliation of the sanitation labour castes has long been perceived as a matter of high stakes-not only for the immediate actors involved, but for the nation. The historical reasons for this are clear enough: with the growth of representative bodies in the initial decades of the 20th century, that fifth of the people of South Asia then known as 'untouchables' and Depressed Classes was transformed, for the first time in history, into an enumerated community (Kaviraj 1992) whose vast numbers made it the decisive factor in the determination of whether India had a Hindu majority or not. As the Arya Samaj and Congress leader Swami Shraddhanand pithily put it in the early 1920s, 'If all untouchables became Muslims then these will become equal to the Hindus, and at the time of independence they will not depend on the Hindus, but will be able to stand on their own legs' (Jordens 1981: 141). To this terrifying prospect there was only one solution: 'their assimilation in the Hindu polity is the very plinth on which alone the edifice of free India can be constructed' (Jordens 1981: 163). The rancorous debate between the Muslim League, Congress, 'untouchable' leaders and the colonial administration over how the Depressed Classes should be categorized in terms of religion is a story that remains largely obscured in the historiography of the period until the moment of its 'resolution,' the Poona Pact of 1932, in which Gandhi wrested from the colonial state governmental approval of his discursive framing of untouchability as a problem internal to Hindu society and thus of 'untouchables' as Hindu. ${ }^{2}$ While this framing ushered in a new governmental and sociological commonsense-the same commonsense that remains with us today-it did not quell the anxiety that Dalit religious autonomy provoked, and continues to provoke, in a broad spectrum of Indian nationalist thought and practice.

5 If nothing short of the existence of a Hindu majority rests on the question of Dalit religion, within the Dalit population the sanitation labour castes have historically played a unique role both in the struggle over this question and in its representation. There are multiple reasons for this, including the numerical preponderance of the sanitation labour castes in regions of intense interreligious competition: in some districts of Punjab they constituted more than ten percent of the overall population in the colonial period (Ibbetson 1970: 290-92). Also significant is the trans-regional spread of the most populous of the sanitation labour castes: unlike most Dalit castes, which were largely confined to particular linguistic regions, the labour migrations of the Chuhra caste under Mughal, Maratha and British dispensations brought them in numbers to cities and cantonments 
from Karachi to Calcutta and Amritsar to Hyderabad. Their being the most pan-Indian of the Depressed Classes, alongside the nature of their labour in the city, made them highly visible to a nationalist elite newly concerned with the 'untouchable' problem. Gandhi further heightened this visibility by presenting the sanitation labour castes-whom he referred to as Bhangis-as a synecdoche for all of the Depressed Classes (Zelliot 1998: 155, Prashad 1996: 552). Indeed, so large did the sanitation labour castes loom in Gandhi's representation of the caste question that the number of references to 'Bhangi' in his collected writings and speeches is higher than the number of references to Chamar, Dhed, Mahar, Mala, Paraiyar/Pariah (to name a few prominent Dalit castes), Rajput, Baniya, and Shudra combined. ${ }^{3}$

Thus, in terms both of the actual numbers of the sanitation labour castes and of their prominence in the nationalist imagination, the stakes of the contest over their religious identity were high. Relative to its historical and contemporary importance, this contesta century-old, ongoing series of interlocking struggles over names, practices and ideologies, spread across the subcontinent, into which our story of mass renaming in Lucknow is an illuminating entry point-has attracted little scholarly attention. The few existing accounts make sense of the rise of the Valmiki title and claims of Hindu belonging in one of three ways. First there are scholars in religious studies who have sought to explain the puzzling link between the sanitation labour caste and the putative author of the Sanskrit Ramayana, whose impeccable Brahmin lineage is multiply attested within the epic, by tracking the name Valmiki through a range of Sanskrit and vernacular religious texts (Sahdev 1997, Leslie 2003). While these accounts do not address the modern period in which the link was actually forged, they make the significant discovery that there have been many Valmikis-the literary traditions of South Asia feature at least seven distinct figures by this name-which helps to explain the context in which Arya Samaj activists were able, in the early 20th century, to conflate a magician and swineherd of Dalit oral tradition with the Sanskrit poet of high brahminical tradition. A different approach is taken by Bhagwan Das (1973) and Vijay Prashad (2000), who emphasize that the adoption of Valmiki is a 20th century phenomenon and describe the process as 'Hindu becoming' (Hindu bannāa) and 'Hinduization,' respectively. The third set of accounts characterizes the same process as one of 'Sanskritization,' M.N. Srinivas's term for the attempt by subordinated castes to improve their social status by adopting the cultural practices of the privileged castes (Shyamlal 1984, Jaoul 2011, O'Brien 2012: 193-94). Nicolas Jaoul, though, modifies the concept considerably in his rich ethnography of the conflict over Valmiki in Kanpur; what he finds is an 'institutionalised and politically engineered Sanskritisation rather than the kind of cultural spontaneity with which Sanskritisation is usually equated' (Jaoul 2011: 280).

7 In conversation with these accounts, I will describe in this article moments in the contest over the religious identity of the sanitation labour castes as it transpired in Lucknow in the middle decades of the 20th century. Of the many loci of change I will foreground transnomination-the renaming of persons using hinduānā rather than musalmānā names -because it throws into relief three highly consequential aspects of the transformation of the sanitation labour castes that are absent or understated in the existing studies. First, to focus on naming practices is to glimpse the stark alterity that characterized the sanitation labour castes' self-understanding vis-à-vis Hindus prior to the Valmiki movement. This, as I will elaborate shortly, is why our subject does not conform to even a modified version of the Sanskritization model. Second, the circumstances under which 
most Lal Begis in Lucknow were renamed points to hitherto unexamined dimensions of political engineering. While Prashad emphasizes the role of Hindu municipal officials in Delhi and Jaoul demonstrates that state-level Congress politicians in UP also worked to promote the Valmiki movement, my findings reveal that in collaboration with these government actors, the Hinduizing cause was given a decisive impetus by the national level Congress administration in the form of its Constitution (Scheduled Castes) Order of 1950. Third, the sweeping success of the effort to transform naming practices in Lucknow, when compared to the fierce and ongoing internal controversies over other aspects of the Valmiki movement (e.g., whether to venerate Lal Beg or Valmiki, how to conduct life cycle rituals, what degree of intimacy to maintain with Muslim neighbours), suggests that for much of the community, there is a politics of tactical dissimulation at work: appearing to accept the offer of majoritarian inclusion, while retaining, with varying degrees of secrecy, autonomous traditions. Here the Lucknow material provides an important counterexample to studies in which Dalits, and in particular urban Valmikis, are enrolled in projects of Hindu majoritarian violence (Prashad 2000, Narayana 2009, Jaoul 2011). Analytically isolating transnomination from other aspects of the contest over religious identity enables us to question whether the nominative Hinduization of the sanitation labour castes constitutes the Hindu majoritarian triumph that it appears to be.

Before turning to our main narrative-how the Lal Begis of Lucknow became Valmikis-a few matters remain to be clarified. In the next section, after briefly explaining my disquiet with the Sanskritization model, I will consider one of the earliest critical assessments of the Valmiki movement-Ambedkar's-and relate it to the regime of recognition that the Poona Pact of 1932 put in place and that the Constitution (Scheduled Castes) Order of 1950 chiselled into law. This is necessary in order to understand the decisions Lucknow Lal Begis made in the following decades. The subsequent section introduces the sanitation labour castes of Lucknow in more detail.

\section{Recognition in the New Regime}

Nicolas Jaoul's formulation of the adoption of Valmiki as 'politically engineered Sanskrisation' is salutary in that it both draws our attention to the political content of the particular history in which we are interested and politicizes the concept of Sanskritization more generally. At the same time, though, the culturalist frame of Sanskritization that Jaoul rightly criticizes is not the concept's only problem. ${ }^{4}$ Equally fatal in the Dalit context is that Sanskritization, like Dumont's 'whole' and Alfred Lyall's organic model of Hinduism, plots all of subaltern religious life into a brahminical narrative. This is erroneous: neither is brahminical Hinduism a necessary telos of subaltern religiosity-as the social history of vast communities like Jats and Julahas will confirm $^{5}$-nor does it inevitably pervade the 'tribal' context that such narratives take as their starting point. On the contrary, the assumption, implicit in many uses of the concept of Sanskritization, that before their efforts at upward mobility, subaltern groups lived in a kind of transhistorical, proto-Hindu condition-that they were waiting in the wings of Hinduism, as it were-is a clear case of the backward projection of modern categories, a projection that does violence to the self-representations of at least some of these groups. The Lal Begis, as we will see, were among those who gave voice to their alterity from the Hindus before the campaign to adopt Valmiki became popular. For this 
reason, Sanskritization, insofar as it implies upward movement within, rather than a rupture of religious boundaries, is not a fit concept for the phenomenon at hand.

It is important to bear in mind that the common-sense that imagines the subaltern communities of South Asian history to have been Hindu or proto-Hindu by default was not securely in place in the early decades of the 20th century. In the period before the Poona Pact, the religious 'identity' of the Depressed Classes was by no means a settled question, and it remained a possibility, however slight, that the colonial state could confer recognition on the de facto autonomy of the various religious communities that caste subalterns understood themselves to constitute, as it did, briefly, with the Ad Dharmis in the 1931 census (Juergensmeyer 2009). This prospect died, however, in the wake of Gandhi's 'epic fast' against the communal award; the Poona Pact politically ratified the discursive confinement of the Depressed Classes within the category of the Hindu (Tejani 2007, Conrad 2007, Adcock 2014). As Gandhi triumphantly put it to Ambedkar in February 1933, 'In accepting the Poona Pact you accept the position that you are Hindus [...] You cannot escape the situation that you are Hindus in spite of your statement to the contrary' (Gandhi 2000: vol. 59, Appendix X).

11 If the Poona Pact framed the terms of a new regime of recognition, it did not abolish the old common-sense overnight, and traces of the preceding state of affairs remained even in governmental practice. There were Muslim and Sikh castes listed among the colonial government's first 'schedule' of 1936, for instance. Upon independence, however, the Congress eliminated these contradictions. The Constitution (Scheduled Castes) Order of 1950 unequivocally stated that 'no person who professes a religion different from the Hindu religion shall be deemed to be a member of a Scheduled Caste.' Combined with the raft of political safeguards and economic and educational benefits that the Constitution and subsequent legislation made available to Scheduled Castes, this religious restriction on state recognition of disadvantaged status worked, in effect, as a national governmental incentive to 'profess' the Hindu religion. As we will see, its consequences in Lucknow were considerable.

Ambedkar's assessment of the Valmiki movement-one of the earliest-reflects the discursive imprisonment of the 'untouchable' within the house of Hinduism that the Poona Pact helped bring about. In his essay 'Away from the Hindus,' written in the years following the Poona Pact, Ambedkar wrote the following:

There is a general attempt [by Untouchables] to call themselves by some name other than the 'Untouchables' [...] the Bhangis call themselves Balmikis. All of them if away from their localities would call themselves Christians [...] they give themselves other names which may be likened to the process of undergoing protective discolouration [...]

The name matters and matters a great deal. For, the name can make a revolution in the status of the Untouchables. But the name must be the name of a community outside Hinduism and beyond its power of spoliation and degradation. Such name can be the property of the Untouchable only if they undergo religious conversion. A conversion by change of name within Hinduism is a clandestine conversion which can be of no avail (Ambedkar 1989: 419-20).

In judging the adoption of Valmiki as a 'change of name within Hinduism,' Ambedkar implies that the 'Bhangis' were 'within Hinduism' in the first place. Whether he was aware of the degree to which the sanitation labour castes of north India understood themselves to constitute a distinct religious community is difficult to know. But to whatever extent he was acquainted with the traditions of Lal Beg, in the passage quoted 
Ambedkar cedes the ground that Gandhi so keenly sought him to cede: that the 'untouchables' are to be considered Hindu by default. Deprived of a political discourse that would recognize the autonomy of already existing Dalit religious traditions, Ambedkar had by this time committed himself to an emancipatory project that accepted the terms of the categorical schema installed by the Poona Pact as a starting point-he acquiesced to being defined as Hindu ${ }^{6}$-but sought to escape this confinement by conversion.

Given this context, it is unsurprising that Ambedkar gives a negative view of the adoption of Valmiki as ineffectual or even damaging as a means of 'untouchable' emancipation. On another occasion Ambedkar is reported to have said that 'Valmiki is a one-man advertising agency for Ram Rajya' (Prashad 2000: 154). For our purposes, Ambedkar's assessment of the politics of the sanitation labour castes is important for an additional reason. His characterization of their adoption of new names as 'undertaking protective discolouration' perceptively suggests a theme in evidence in the identitarian struggle in Lucknow. Throughout the colonial period the sanitation labour castes were described as 'chameleon-like in their copying of the externals of other faiths' (Griswold 1934: 227; cf. Strickler 1926, Rose 1902, Burn 1902). The oral traditions of the community valorise the subaltern tactic of dissimulation, particularly in the domain of religious practice: appearing to conform to the religious norms of political overlords while discreetly maintaining autonomous rites. This kind of furtive politics did not end in the colonial period but perdures in my interlocutors' stories of the post-independence period, as well as in silences, smiles, gestures, and other non-verbal signs. In flagging this dimension of the sanitation labour castes' apparent embrace of Valmiki, then, Ambedkar, unlike subsequent observers of the same process, alerts us to that which makes the Lucknow story so distinctive. His evocative phrase 'clandestine conversion' is thus both accurate and misleading: the adoption of Valmiki was indeed a 'conversion' of sorts-a donning of the mantle of a new religion. But it was not the claiming of Hindu identity that was 'clandestine'-this took place rather out in the open. What was 'clandestine' was not the embrace of Valmiki but the retention-in back rooms, away from the reformist gaze-of the old, non-Hindu ways of Lal Begi ancestors.

\section{The Sanitation Labour Castes, Lal Beg, and the 583}

But what was this Lal Begi tradition, what kind of religious community did it imagine, and to what extent were the practices of the sanitation labour castes of the Lucknow region distinctive from those of their caste fellows elsewhere in the subcontinent?

First I should separate out terms in what is a very dense and complex field of nomenclature. The protagonists of our story have been known by a welter of names: titles of specific castes (Chuhra, Dom, Dhanuk, Hela, Bansphor, and others), occupational labels that transcend caste specificity (Khakrob, Halalkhor, Jamadar, Mehtar, sweeper, scavenger), religious titles that come to connote caste belonging (Lal Begi, Valmiki), and the hotly contested appellation 'Bhangi.' By 'sanitation labour castes' I mean to denote all of the preceding: those Dalit castes that perform the vast majority of sanitation work in contemporary South Asia. The term is a translation of safāi kāmgār jātiyān, a selfdesignation used by ordinary people, by Hindi writers who take up the topic, and by a number of non-governmental organizations whose members belong to these castes. By using the term I do not mean to endorse or reproduce the brahminical social ideology 
that reifies the contingent link between a people and an occupation-a concern thoughtfully raised by Ramnarayan Rawat (2011) - but rather to acknowledge, with my interlocutors, the extraordinary degree to which this domain of work impinges on their lives.

Songs, stories, rites and practices related to Lal Beg constitute one sphere in which the distinct sanitation labour castes appear to have found common ground. It is not clear to what extent all of the castes participated-Chuhras and Dhanuks certainly did (Rose 1902: 183-86, Strickler 1926, Ibbetson 1970: 294-96), whereas Doms may not have-but to many observers the veneration of Lal Beg appeared so widespread across regions and communities that the title Lal Begi, meaning disciple of Lal Beg, was used as a synonym for sweeper (e.g., Fallon 1879: 303, Dihlawi 1898: 165, Azad 1907: 394, Kipling 1901:15859). In oral traditions recorded by missionaries, folklorists, administrators and ethnologists in Punjab, Bengal, the Deccan and the United Provinces in the late 19th and early 20th centuries, Lal Beg (literally 'Red Lord'), also known as Bala Shah, was a prophet (nabi, paighambar) and guru created by god (alif allah, khuda, rabb, akal purakh) who lived among the sanitation labour castes and secured their salvation in the afterlife. In songs and legends Lal Beg is miraculously born from a pot in Ghazni, eats bread baked by Fatima, wins praise from 'Ali, sweeps the steps of heaven (bihisht), rescues the sweepers of Delhi from an enraged emperor, drives camels in Kashmir, conquers Kabul, and generally leads an extraordinary life (Ibbetson 1970, Temple 1884A, 1884B, Greeven 1894, Youngson 1906:340-54, Kaul 1911:131-33, Strickler 1926: Ch 3). To the extent that there are historical referents in the corpus of Lal Begi oral traditions, they are largely Mughal; the theological vocabulary is heavily Islamic, though Sikh terms and concepts also appear.

How did the Lal Begis perceive themselves vis-à-vis other religious communities? The oral traditions suggest a community that understood itself as other to Hindus, Muslims, and Sikhs. Lal Begi liturgical songs transcribed in the late colonial period have as one remarkable feature usages of the terms Hindu and Muslim as contrastive to the Lal Begi self. Some of these usages relate to the shrines of Lal Beg, which are affirmed as distinct from the religious architecture of other communities. One of the songs performed at the annual feast of Lal Beg in Benares, for instance, contains the line 'The Hindu has his temple, the Muslim his mosque, but I give to you this altar of mud' (Greeven 1894: 43, 48). ${ }^{7}$ Another song, transcribed in Punjab, presents a similar sentiment: 'As Hindus revere the Ganga, as Muslims have their Mecca, so the Shahis [another name for Lal Begis] adore your name and build your shrines in every village' (Youngson 1906: 343 ). ${ }^{8}$ In these verses, the Lal Beg shrine is contrasted with its correlates in the religious communities of others.

Some of the clearest assertions of Lal Begi difference from other religious communities are soteriological in nature. There are a number of stories and songs that imply, more or less explicitly, that Hindu, Sikh and Muslim paths to salvation are false or inferior to that made possible through Lal Beg. A representative example is a song transcribed in Sialkot District, in which a Lal Begi ancestor petitions God:

Hindus forbid my approach

Muslims refuse to bless my dead

Listen, O God

I want to form my own nation [ummat ${ }^{9}$

God assures the sufferer, by means of a letter delivered by Lal Beg, that:

On the Day of Judgment [qayāmat]

Only you will be blessed [...]

The partisans of Ram and Rahim 


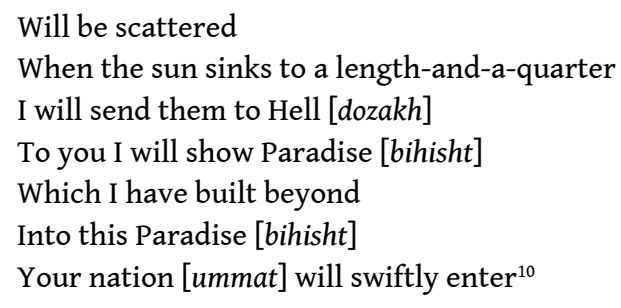

21 Here the Lal Begi tradition enunciates a soteriological claim neither ambiguous nor inchoate-as the axioms of subaltern religions are often represented to be-but all too clear: on the Day of Judgment, it is the long-suffering Lal Begis, beloved of God, who will attain paradise, while their earthly oppressors, here specified as Hindus and Muslims, will suffer in hell.

Before the movement to adopt Valmiki spread across north India, there is scant evidence for what the naming practices of the sanitation labour castes were-at least in terms of personal names. From the family histories that I collected in Lucknow and its surrounding districts, it is clear that musalmānā names predominated for both women and men in that region until the middle of the 20th century. Valmikis today sometimes attribute their grandparents' Muslim-styled names to the mimetic tactics already mentioned-the adoption of the outward practices of the locally dominant group, jais $\bar{a}$ rājā vaisi prajā (as the king, so the people). And indeed Awadh was a region with a relatively high proportion of Muslim landowners (Nevill 1904, Hasan 2007). But this explanation does not hold for other parts of north India: there is some evidence that musalmānā names were common among the sanitation labour castes in the Shimla area (Bhagwan Das, personal communication) and 'Muslim names like Akbur, Jamal, Multan, Data Deen, Aladeen, etc.' were the norm among 'Bhangis' until about 1930 in Jodhpur, another place lacking a significant Muslim landowning presence (Shyamlal 1984: 30). I would venture that before the Valmiki movement, personal names among the sanitation labour castes reflected the Islamicate world of the Lal Begi liturgy at least as much as it mirrored the naming practices of the locally dominant caste.

There is one more name that we must introduce. In Lucknow two of the sanitation labour castes of north India predominate: Chuhras (in the cantonment, the old city, and north of the Gomti) and Dhanuks (in the city's western and southern quarters). The two have followed different identitarian trajectories and in this article I am discussing only the former. Most of the Chuhras of Lucknow belong to a group known as the Pāñch Sau Tirāsithe 583. The 583 are a regional clan (the usual word is the Arabic qabila: 'tribe; clan; family' [Platts 2000: 788]) or unit of self-governance (panchāyat) of the Chuhra caste in Awadh. There are other such regional clans in central UP-the Hazara (Thousand) of Mahmoudabad and the Bāra Ghar (Twelve Houses) of Sitapur, for example-but the 583 constitute by far the largest clan in Awadh. Their traditional territory stretches between the Gomti and the Ghaghra rivers from Sitapur in the northwest to Faizabad in the southeast: the better part of six administrative districts. At the geographical center of this territory stands Dewa Sharif, a complex of Sufi shrines in Bara Banki district where the 583, until quite recently, convened meetings of the panchayat or caste council. The 583 trace the origins of this institution to one Jumma Mehtarani, a sagacious (dimāghdār) ancestress whose strategic dealings with her royal employers won the caste concrete benefits in land, patronage and protection. Some say she came from Iran or accompanied Babur's Mughal army; others place her centuries later, as an accomplice of Begum Hazrat Mahal, the queen of Awadh known for sponsoring the insurgents against the British in 
the great rebellion of 1857. Other than their unique foremother, the 583 have traditionally distinguished themselves from their caste fellows in other regions by various occupational and dietary practices, several of which relate to swine: in addition to sanitation work, the 583, unlike the chuhra caste elsewhere, rear and trade mules, donkeys and horses, and do not rear or sell swine. Nor do they eat pig flesh, whereas in many parts of north India the consumption of pork is central to Chuhra ritual life. Lastly -and this is to get ahead of the story-the 583 are known today for their continuing attachment to the old ways. If there remains a bastion of the once-ubiquitous Lal Begi tradition in north India, it is in Lucknow and the villages of Awadh.

Having introduced our protagonists, let us now turn to how they came to be renamed.

\section{Lal Beg versus Valmiki, Deg versus Bhagaunā}

In Lucknow and its hinterland, it was largely the first generation of Congress MLAs and MPs $^{11}$ from the sanitation labour castes, most of whom were also Arya Samajists, who led the movement among their caste fellows to abandon Lal Beg and adopt Valmiki from 1947 onward. They convened meetings in the bastis of Lucknow where they performed bhajans of their own composition and pressed their caste fellows to reform. Munnu, a sanitation workers' union leader who witnessed such performances in his childhood, recalled to me the reformists' message in this way:

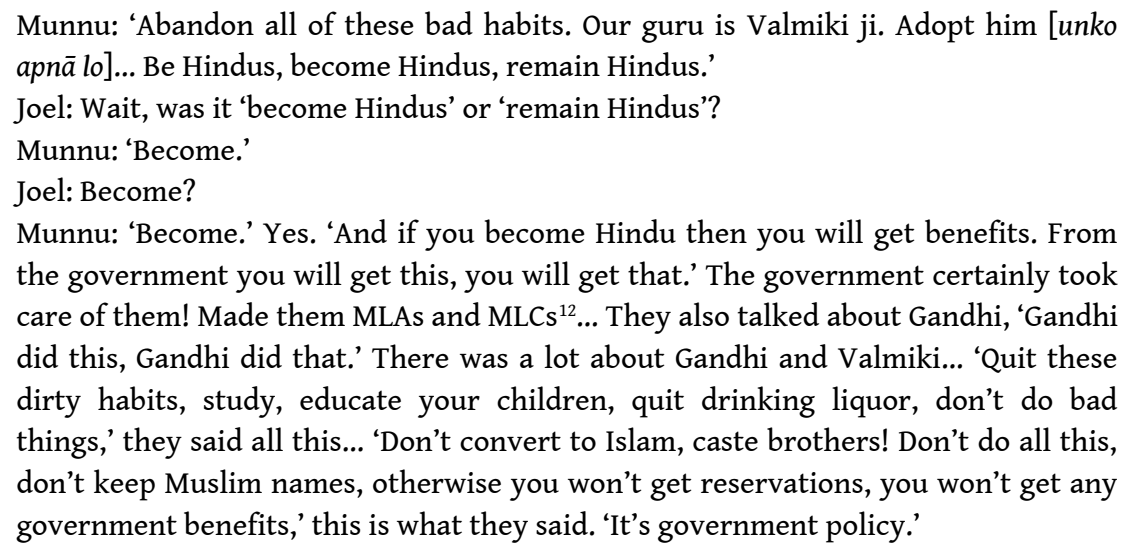

The sardonic edge to Munnu's remarks is not unrepresentative. Many in the community were put off by the wholesale criticism of tradition put forward by the young, Congressbacked, aspiring caste leaders. One of the reformists' best-remembered verses-authored, significantly, by a non-583 from the cantonment-was this:

Lal Begi nām chhoro, rishiyon kī santān ho

(Abandon the name Lal Begi, you are the descendants of sages)

Here Valmiki (the sage referred to) was figured in contrastive opposition to Lal Beg; the reformers held that to embrace Valmiki as the caste progenitor was, perforce, to abandon allegiance to Lal Beg. In response to this hectoring refrain, quipsters among the 583 composed verses of their own that inverted the attack and ridiculed Valmiki and his advocates. For example:

Netwā āye, netwā āye, hamkā jhānț mìki batāran

('Leaders' have come, 'leaders' have come, they're saying our pubic hairs are 'miki')

Mïki is a nonsense word that, conjoined with jhänt (pubic hair), rhymes with Valmiki. The quip thus corrupts and parodies the speech of the reformists; their oft-repeated phrase 
'You all are not Lal Begi, you are Balmiki' becomes 'You are not Lal Begi, your pubic hair is miki.' I heard several versions of this witticism from elderly interlocutors on both sides of the reformist divide. leadership and the reformists. Everything was fought over: what rites to perform, whom to invite, what food to prepare, whether or not to serve liquor, whether or not to have the fâtiha (Quranic prayers) recited over the meal, and so on. Symbolically the conflict crystallized into the struggle between the deg and the bhagaunā. Both are large metal cauldrons used for cooking over an open fire; the only necessary structural distinction is that degs are rounded whereas bhagaunās are cylindrical with a flat bottom. But for complicated reasons the deg has come to represent 'Muslim' cooking whereas the bhagauna is taken to be a 'Hindu' vessel. In Lucknow the Lal Begis had long used degs to prepare their wedding meals because Muslims willingly rented them out (or sometimes lent them for free), whereas Hindus refused to allow the sanitation labour castes use of bhagaunās even when they could pay. With the arrival of Valmiki, though, the reformists began to rail against the use of the deg at weddings because the Hindus they had begun to invite to their weddings (friends in the Congress and Arya Samaj) would not eat food prepared in a deg-even if the dish were vegetarian. The reformists established a cooperative (within the caste) for wedding equipment-bhagaunās and cooking utensilsfrom which members could borrow when the occasion arose. They began to boycott weddings (and funerals) at which degs were used or the fattiha recited. Rancour ensued, divisions hardened, and a series of accusations and counteraccusations led to a civil case being brought before the city magistrate, who decided in favor of the reformists. The result, though, was not resolution but a simmering factionalism that continued to erupt in smaller disputes every few years for decades. Degs gradually disappeared from 583 weddings, and the fātiha is no longer recited. But the reformists did not win a total victory: even in the now-ubiquitous bhagaunās, it is not vegetarian fare, but biryani and goat curry that continues to be cooked and served at most Valmiki weddings in Lucknow.

If much of the contest over the religious identity of the sanitation labour castes of Lucknow has had an agonistic character of this kind, the change in naming practices provides a significant contrast. More than other objects of reform, naming practices were pragmatically linked to education; since education was widely desired in the community, the revolution in naming practices that accompanied the admission into schools of a generation of sanitation labour caste youth in the 1950s and 1960s proved the least contested aspect of the reformist project within the community. That is to say, the destruction of Lal Beg shrines and efforts to prevent the serving of meat at weddings incited resentment and dissention in the community to a far greater degree than the equally unprecedented application of Hindu-styled names to an entire generation of children. It is my argument that the relative ease with which this transnomination was secured has a great deal to do with the constitutional requirement that Dalits 'profess' Hinduism to be recognized as Scheduled Caste-the post-independence regime of recognition that Dieter Conrad (2007: 216) has called 'legal Hindutva.'

South Asia Multidisciplinary Academic Journal, 11 | 2015 


\section{Jagdish, son of Ahmad}

Shuru mai merā nām muslim thā. [Originally my name was Muslim.]

This utterance, or a variation on it (usually musalmānā rather than muslim), was so frequently given voice in my interviews with Lucknow Valmikis born before the 1980s that I learned to expect it. Many stories of renaming that I heard resonated with that of Rishi Kumar, a poet, song-writer and retired hospital sanitation worker born in the 1940s:

Rishi Kumar: Originally my name was Muslim. Hasanu. That was the name I was given at first $[. .$.

Joel: Your parents, sisters, brothers, everyone called you by this name?

Rishi Kumar: Earlier they called me by this name. Now everyone knows me as Rishi Kumar.

Joel: Did you change it yourself?

Rishi Kumar: No, no, my name, in truth, changed on account of my studies. When I was studying, that's when my new name got written [likhā gayā].

Joel: Do you remember how it came about?

Rishi Kumar: Yes, my father had it written. My father said, 'His name is not good. In the future it will cause problems, give him trouble. In studying, in going other places, it will cause him difficulties.' So he renamed me according to his own thinking. There was an MLA, one Kanhaiya Lal Balmiki [a major reformer and champion of the movement to embrace Valmiki]. He had a brother named Rishi Kumar. I was renamed after him. [...] My name was changed in 1955. It was when my name was recorded at school. When admissions happened, the form was filled, at the time of filling the form my name was written as Rishi Kumar.

Rishi Kumar was not singled out for this treatment. His parents changed their names as well:

My father's original name was Rahim. Later, when we came here from the village, he took the name Ram Das. [...] My mother's name was Hafiza, but afterward it was changed to Ganga [...] because it would be difficult for her to go to temples; when she would say 'My name is Hafiza,' they wouldn't easily let her enter the temple.

The nominative practices of virtually the entire 583 clan transformed between the late 1940s and the 1970s. With regard to his mother, Rishi Kumar mentions the 'difficulty' [ dikkat] of entering Hindu temples bearing an apparently Muslim moniker. This is relatively rarely cited as a factor in transnomination, though it is worth noting that names did function as one of many signs of Lal Begi alterity from Hindus in the old order. A more common context for adopting hinduānā names was the obtaining of government employment. In many accounts, women and men changed their names precisely when they applied for positions as sanitation workers in the municipality, at the university, or in government hospitals. Rishi Kumar hints at this when he remarks that Rahim became Ram Das 'when we came here from the village.' For his parents, as for many of the 583 who urbanized in the middle decades of the 20th century, leaving the village and joining government service were simultaneous, almost coterminous, events. Relatives or caste fellows who had migrated to Lucknow earlier and already held government jobs advised them to apply for work with hinduānā names. Having musalmānā names, especially in the years immediately following independence and partition, was seen as a liability, a potential source of 'difficulty' [dikkat] or 'trouble' [pareśānī], for fourth class employees in government departments where anti-Muslim sentiment sometimes ran unchecked. Transnomination at the moment of securing government employment was, for a period, 
so widespread that it gave rise to the term 'sarvis nām' [service name], the hinduānā name used for employment purposes, as distinct from 'ghar kā nām' [home name], the often musalmānā name used among family and community.

More than any other, though, it was the context of Rishi Kumar's own renaming-school admission-that prevailed in my interlocutors' accounts. The reformists consistently stressed the practical value of the adoption of hinduāna names-both given names/ forenames and the surname Valmiki-in securing admission to government schools and exemption from school fees. Education, and the governmental financial assistance that brought education potentially within reach, were themes rarely absent from the appeals the reformists made to their caste fellows. As the reformer Lalta Prasad put it, their message had as its refrain the following: 'Brothers, we people are not Lal Begi but Balmiki. We should write 'Balmiki' [as our surname]. And by doing this we will get exemptions from fees, our daughters and sons will get fee exemptions. If we write 'Lal Begi' then they will not get scholarships and fee exemptions.' He then described a particular incident from around 1960:

I had this friend. There was a Gitā Vidyālāy [a government-supported school in our neighbourhood, run by prominent local Congressmen]. They had a column on the application for admission asking what your religion is. Isn't it? So my friend wrote 'Lal Begi.' He submitted the forms. Then [the admissions officer] said 'Kindly pay the full fees.' My friend replied, 'Why?' So [the admissions officer] said, 'You are Lal Begi, Muslim. Therefore you will have to pay full fees.' So he came and told me about it, and told Govind Prasad, and we advised him, 'You've made a mistake, bring the forms to us, we'll fill out a new one.' So the second form we filled out, and we wrote 'Balmiki' and in brackets 'Hindu.' Meaning Scheduled Caste. [...] Then he did not have to pay fees.

Awareness of the legal recognition of the category of Scheduled Caste, and of state programs designed to address caste-based inequality by creating educational and other opportunities for Scheduled Castes, arrived in the bastis of Lucknow piecemeal in the years after the Constitution took effect. Lalta Prasad's friend knew that under Congress rule, his caste status should entitle his children to a fee exemption in school, yet he remained unaware of the religious exclusions that qualified that entitlement. Having naively identified himself according to his community's traditional self-description-as Lal Begi by religion-he found himself confronted by a legal regime for which the de facto autonomy of Dalit religion was illegible. That is, he experienced locally the Constitution (Scheduled Castes) Order: professing a religion 'different from the Hindu religion,' he was not 'deemed to be a member of a Scheduled Caste.' The admissions officer-the local face of the state-understood Lal Begis to be Muslim, or at least to be more akin to Muslims than to the other recognized religious communities, and accordingly declared the family ineligible for financial relief. Since even modest school fees were beyond the means of Lalta Prasad's friend-as they were for most sanitation labour caste families-securing his children's education meant formally relocating his family vis-à-vis the state's regime of recognition. It meant becoming-or at least professing to be-Hindu.

Gauhar Lal, born in 1939, a retired government accountant and one of the most highly educated members of the community in his generation, told the following story of his own experience in accessing education at a government school in Lucknow:

I filled out the scholarship form for intermediate [eleventh and twelfth standard]. On the form, for religion, for caste I wrote Mehtar. And I was disqualified ${ }^{13}$ for scholarship. I didn't get it. They said, 'This is not allowed.' So the principal called me and said, 'You've written Mehtar as your caste, why didn't you write Balmiki?' I 
said, 'What is Balmiki? I don't know Balmiki.' He said, 'This has been recognized, from the government this has been already recognized, that only Balmikis will obtain scholarships.' So I got a magistrate-an acquaintance-to make out a certificate saying 'Now I am Balmiki.' [...] So when I got the Balmiki certificate, and again sent the form, then I got the scholarship.

Such stories were legion. Sometimes only the children's surname or title was changed (from Lal Begi or Mehtar to Balmiki), other times the given name was changed as well. Not infrequently, the parents changed their names at the same time, in order to avoid scrutiny by admissions staff, or embarrassment to their children, on account of the mixture of musalmānā and hinduānā names in the same family. Ratan Lal 'Sadhu' (born in 1948), for instance, told me that:

When I went to school, one of our community leaders said to me, 'Your father's name is Ali. This will not do, your classmates will laugh at you [...] So in place of Ali, write Alok Nath.' [...] So then-my father's real name [asli nām] is Ali-then for school papers I wrote that my father's name was Alok Nath. And to this day he's known as Alok Nath.

\section{Conclusion}

If the above account appears to take a narrowly instrumentalist view of the politics of the Valmiki movement in Lucknow, it is because so many of the women and men who related to me the stories of their and their families' renaming emphasized precisely this aspect. Not every front in the Hinduizing campaign looked like this: the efforts to encourage vegetarianism, to discourage the rites of Lal Beg, and to introduce cremation instead of burial, for example, made less frequent reference to the state and fewer direct appeals to calculations of self-interest, though the latter were by no means absent. As the case of the degs and bhagaunās was meant to illustrate, these and other domains of reform were also more hotly contested, and remain divisive issues in the community today.

But while meat remains popular at Balmiki weddings in Lucknow, burial continues to vie with cremation, and the rites of Lal Beg persist (albeit in increasingly secretive forms), the Islamicate repertoire of personal names with which the community formerly named its children, and the title Lal Begi itself, have virtually disappeared. In no other sphere of the Valmiki movement have the advocates of Hinduization achieved a more complete success. As we have seen, this had partly to do with the advantage hinduāna names gave their bearers in obtaining jobs in the municipality and in government hospitals and universities in the years following Partition-a consequence, in other words, of the normalization of anti-Muslim sentiment in the Congress administrations in UP and in Lucknow city government. This gives further support to the contention of Prashad and Jaoul that municipalities operated as crucial sites for the induction of the sanitation labour castes into the project of Hindu majoritarianism.

41 Even more than employment, though, we have seen that it was access to education that decisively influenced naming practices in the accounts of Lucknow Balmikis. This reveals a dimension of the political engineering of subaltern Hinduization hitherto neglected in the analysis of the Valmiki movement, and the literature on the postcolonial politics of caste and religion more broadly. The religiously exclusionary definition of the Scheduled Castes inscribed into law by the Constitution (Scheduled Caste) Order of 1950-a postcolonial echo of the Poona Pact-effectively brought into being a raft of powerful material incentives for Dalits to 'profess' to be Hindu, chief among them being 
scholarships and student fee exemptions. In the Congress dispensation of the 1950s onward, Ahmad and Ayesha had to become Ganesh and Gayatri to afford schooling.

Nominative politics, however, cut both ways. If the 1950 Order and the de facto policies of Congress municipal administrations ushered in a wave of transnomination and produced a generation of apparently Hindu youth, these conversions were not without their clandestine continuities. Recall the frank instrumentalism of Ratan Lal 'Sadhu,' who appreciated the 'profit that accrued to us upon becoming Hindu,' as well as his equally unguarded remark, 'my father's real name [asli nām] is Ali.' When the sanitation labour caste tradition of 'undergoing protective discolouration' is taken into account, the very ease with which the revolution in names was secured casts doubt on the nature of this apparent triumph of the Hindu majoritarian project.

\section{BIBLIOGRAPHY}

Adcock, C.S. (2014) The Limits of Tolerance: Indian Secularism and the Politics of Religious Freedom, New York: Oxford University Press.

Ambedkar, Bhimrao Ramji (1989) Dr. Babasaheb Ambedkar: Writings and Speeches, vol. V. Vasant Moon (ed.), Bombay: Education Department, Govt of Maharashtra.

Azad, Muhammad Husain (1907) Ab-i Hayat, Lahore: Naval Kishor.

Burn, R. (1902) Census of India 1901, Volume XVI: N.-W. Provinces and Oudh. Part I. Report, Allahabad: Government Press.

Butalia, Urvashi (1998) The Other Side of Silence: Voices from the Partition of India, New Delhi: Penguin.

Conrad, Dieter (2007) ‘The Personal Law Question and Hindu Nationalism', in Vasudha Dalmia and Heinrich von Steitencron (eds.), The Oxford Hinduism Reader, New Delhi: Oxford University Press, pp. 187-230.

Das, Bhagwan (1973) Bālmīki Jayanti aur Bhangī Jātiyāñn, Delhi: Gautam Book Centre.

Dihlavi, Sayyid Ahmad (1898) Farhang-i Asafiyyah, vol. IV, Delhi: National Academy.

Eaton, Richard (1982) 'The Political and Religious Authority of the Shrine of Baba Farid', in Barbara Metcalf (ed.), Moral Conduct and Authority: The Place of Adab in South Asian Islam, Berkeley: University of California Press, pp. 335-56.

Fallon, S. W. (1879) A New Hindustani-English Dictionary, Banaras: Medical Hall Press.

Gandhi, Mohandas (2000) The Collected Works of Mahatma Gandhi, New Delhi: Ministry of Information and Broadcasting, Government of India.

Greeven, Richard (1894) The Knights of the Broom: An Attempt to Collect and Explain Some of the Ceremonies of the Sweepers of the Benares Division, Benares: Medical Hall Press.

Griswold, H. D. (1934) Insights into Modern Hinduism, New York: H. Holt and company. 
Guru, Gopal (1984) 'Reservations and the Sanskritization of Scheduled Castes: Some Theoretical Aspects', Sociological Bulletin 33(1/2), pp. 29-38.

Hasan, Mushirul (2007) From Pluralism to Separatism: Qasbas in Colonial Awadh, Delhi: Oxford University Press.

Ibbetson, Denzil (1970) Panjab Castes, Being a Reprint of the Chapter on 'The Races, Castes, and Tribes of the People' in the Report on the Census of the Panjab, Patiala: Languages Dept., Punjab.

Jaoul, Nicolas (2011) 'Casting the 'Sweepers': Local Politics of Sanskritisation, Caste and Labour', in Daniela Berti, Nicolas Jaoul and Pralay Kanungo (eds.), Cultural entrenchment of Hindutva: Local mediations and forms of convergence, New Delhi: Routledge, pp. 273-306.

Jordens, J.T.F. (1981) Swāmī Shraddhānanda: His Life and Causes, Delhi: Oxford University Press. Juergensmeyer, Mark (2009) Religious Rebels in the Punjab: The Ad Dharm Challenge to Caste, New Delhi: Navayana.

Kaul, Pandit Harikrishan (1911) Census of India, 1911, Volume XIV - Punjab. Part I. Report, Lahore: Civil and Military Gazette Press.

Kaviraj, Sudipta (1992) 'The Imaginary Institution of India', in Partha Chatterjee and Gyanendra Pandey, (eds.), Subaltern Studies VI: Writings on South Asian History and Society, Delhi: Oxford University Press, pp. 1-39.

Kipling, Rudyard (1901) Kim, New York: Doubleday, Page and Company.

Kumar, Dev (2004) Hā̀n, Hāǹ, Hāñ, Main Bhangī Hūn, Kanpur: Prabhu Prakashan.

Lee, Joel (2015) Recognition and its Shadows: Dalits and the Politics of Religion in India, PhD Dissertation, Columbia University.

Leslie, Julia (2003) Authority and Meaning in Indian Religions: Hinduism and the Case of Valmiki, Cornwall: Ashgate.

Lynch, Owen (1969) The Politics of Untouchability: Social Mobility and Social Change in a City of India, New York: Columbia University Press.

Moffatt, Michael (1979) An Untouchable Community in South India: Structure and Consensus, Princeton: Princeton University Press.

Narayana, Badri (2009) Fascinating Hindutva: Saffron Politics and Dalit Mobilisation, Los Angeles: Sage.

Nevill, H.R. (1904) Bara Banki: A Gazetteer. Being Volume XLVIII of the District Gazetteers of the United Provinces of Agra and Oudh, Allahabad: Govt. Press.

Roberts, Nathaniel (2008) 'Caste, Anthropology of', in William S. Darity (ed.), International Encyclopedia of the Social Sciences, New York: Macmillan Reference, pp. 461-63.

Rose, Horace Arthur (1902) Census of India 1901, Volume XVII: Punjab and North-West Frontier Province, Part I, Report, Simla: Government Central Printing Office.

Platts, John T. (2000) A Dictionary of Urdu, Classical Hindi and English, Delhi: Munshiram Manoharlal. Prashad, Vijay (1996) ‘The Untouchable Question', Economic and Political Weekly 31(9), pp. 551-59. Prashad, Vijay (2000) Untouchable Freedom: A Social History of Dalit Community, New Delhi: Oxford University Press.

Sahdev, Manjula (1997) Maharishi Valmiki-Vyaktitva evam Kritatva, Patiala: Punjab University Press. 
Searle-Chatterjee, Mary (1981) Reversible Sex Roles: The Special Case of Benares Sweepers, Pergamon Press.

Searle-Chatterjee, Mary (2008) 'Attributing and Rejecting the Label 'Hindu' in North India', in Nile Green and Mary Searle-Chatterjee (eds.), Religion, Language, and Power, New York: Routledge, pp. 186-201.

Shyamlal (1984) The Bhangis in Transition, New Delhi: Inter-India Publications.

Strickler, Herbert Johnson (1926) The Religion and Customs of the Chuhra in the Punjab Province, India, MA Thesis, University of Kansas.

Tambiah, S.J. (1967) [Review of Social Change in Modern India by M.N. Srinivas], Modern Asian Studies 1(4), pp. 404-05.

Tejani, Shabnum (2007) 'Reflections on the Category of Secularism in India: Gandhi, Ambedkar, and the Ethics of Communal Representation, c. 1931', in Anuradha Dingwaney Needham and Rajeswari Sunder Rajan (eds.), The Crisis of Secularism in India, Durham: Duke University Press, pp. 45-65.

Temple, Richard (1884a) Legends of the Panjab, Volume I, Bombay: Education Society's Press.

Temple, Richard (1884b) ‘Lal Beg - Lal Bekh - Mehtar Ilias - Pir-I-Dastagir’, Panjab Notes and Queries I: 7.

The Hindu (2015) 'Hindu outfits to resume 'ghar wapsi' without media glare', 20 January.

Tiwari, Mrigank; Abbas, Nazar (2015) 'More than 800 Valmikis 'convert' to Islam in UP's Rampur to save homes from Demolition', Times of India, 15 April.

Youngson, J. (1906) ‘The Chuhras', The Indian Antiquary XXXV, pp. 82-96, 302-10, 337-56.

Zelliot, Eleanor (1998) From Untouchable to Dalit: Essays on the Ambedkar Movement, New Delhi: Manohar.

\section{NOTES}

1. All names of persons in Lucknow in this article have been changed-though the apparent 'Hindu' or 'Muslim' character of the names is carefully retained-to protect the identity of my informants. The only exceptions are public persons (the Member of Legislative Assembly Kanhaiya Lal Balmiki) and the late reformers Lalta Prasad (1923-2014) and Govind Prasad (19262013), who requested, in our many interviews, to be named. Unless otherwise indicated, all quotes are from recorded interviews conducted in Lucknow between February 2011 and May 2012 in Hindi/Urdu, and the English presented here is my translation of the same, with key terms provided in brackets.

2. As C.S. Adcock (2014: 14) rightly notes, 'the premise, now enshrined in the Constitution of India and in much common-sense understanding, that Untouchables are Hindu by religion... was put in place with the agreement between Gandhi and Ambedkar in 1932.' See also Conrad 2007: 198 and Lee 2015:Ch. IV.

3. The only caste categories that are more frequently mentioned than 'Bhangi' in the index of Gandhi's Collected Works are 'Harijan' and 'Brahman.'

4. There has been a host of critical engagements with Srinivas's concept over the last sixty years; for our purposes a few of the relevant critiques include Tambiah 1967, Lynch 1969, Guru 1984, and Roberts 2008. 
5. Julahas adopted Islam in great numbers in the Sultanate and Mughal periods, becoming the single largest occupational Muslim caste of north India; Jats on a similar scale became Muslim and Sikh. See Ibbetson 1970, Eaton 1982.

6. Thus the first part of his famous declaration of the intention to convert: 'I was born a Hindu.'

7. In Greeven's (1894: 43, 48) transliteration, Hindu ka dehra, Mussulman ki masjid; main sewun teri kachchhi marhei. At this point in the song, the speaker is 'Ali and his addressee is Lal Beg.

8. In Youngson's transliteration, Jon Hindu Ganga nu parsann/ Jon Makka Mussalmanan/ Shahi nam tere nu nun mannan/ Pind pind than banavan. Youngson translates the passage thus: 'The Ganges Hindus fear, and Muslims make their weary pilgrimage to Mecca far, but thee the Shahis love and build to thee unnumbered shrines o'er all the crowded land.' (Youngson 1906: 343)

9. Youngson's transliteration of the original oral text is:

Mainun Hindu na nere aun denge/ Mussalman na parhnge janaza/ Tu sun Khuda raja/ Main ummat rakhna chahunan.

10. Youngson's transliteration:

Roz Qiyamat waqt de/ Tainun milegi vadiai [...]/ Ram te Rahim kian/Chhap chhap jana/ Sava neze te din avega/ Haoe dozakh pana/Par bihisht banake/Samne vikhana/Ummat teri bhajjke/Bihishti var jana.

(Youngson 1906: 350-51)

11. MLA: Member of Legislative Assembly. MP: Member of Parliament.

12. MLC: Member of Legislative Council.

13. In this passage italics are used to indicate English words in Gauhar Lal's otherwise Hindi remarks.

\section{ABSTRACTS}

Between the late 1940s and the 1970s, the sanitation labour castes of Lucknow radically altered their nominative practices, replacing Islamicate personal names with names in a Hindu style, and abandoning the caste title Lal Begi in favor of the surname Valmiki. Based on oral histories and ethnographic research with the Valmiki community in Lucknow, the article presents and evaluates evidence for how and why this transformation took place. Building on Nicolas Jaoul's (2011: 280) insight into the 'politically engineered' nature of the consolidation of the sanitation labour castes under the sign of a Hindu sage, the article argues that Congress policy at the national level played a decisive role in the renaming of an entire swath of the Dalit population. At the same time, working with Ambedkar's assessment of the Valmiki movement as 'clandestine conversion' and 'undergoing protective discolouration,' it is argued that the nominative Hinduization of the sanitation labour castes may not constitute the Hindu majoritarian triumph that it appears to be.

\section{INDEX}

Keywords: Dalits, naming, religious identity, Sanskritization, Valmiki, Lal Begi, Congress, Ambedkar, Lucknow 


\section{AUTHOR}

\section{JOEL LEE}

Postdoctoral Research Fellow, Center for the History of Emotions, Max Planck Institute for Human Development, Berlin 